\title{
Population genetic structure of the dengue mosquito Aedes aegypti in Venezuela
}

\author{
Flor Herrera/ ${ }^{+}$, Ludmel Urdaneta, José Rivero, Normig Zoghbi, Johanny Ruiz, \\ Gabriela Carrasquel, José Antonio Martínez*, Martha Pernalete, Patricia Villegas, \\ Ana Montoya, Yasmin Rubio-Palis**, Elina Rojas***
}

\begin{abstract}
Centro de Investigaciones Biomédicas, Universidad de Carabobo Callejón Cecilio Acosta, Avda. Las Delicias, Maracay 2101, Aragua, Venezuela *Departamento de Biología, Universidad Pedagógica Experimental Libertador, Maracay, Aragua, Venezuela **Dirección de Salud Ambiental, Ministerio de Salud y Desarrollo Social, Maracay, Aragua, Venezuela

***Centro de Investigaciones “J. W. Torrealba”, Universidad de Los Andes, Núcleo Trujillo, Venezuela
\end{abstract}

The mosquito Aedes aegypti is the main vector of dengue in Venezuela. The genetic structure of this vector was investigated in 24 samples collected from eight geographic regions separated by up to $1160 \mathrm{~km}$. We examined the distribution of a 359-basepair region of the NADH dehydrogenase subunit 4 mitochondrial gene among 1144 Ae. aegypti from eight collections. This gene was amplified by the polymerase chain reaction and tested for variation using single strand conformation polymorphism analysis. Seven haplotypes were detected throughout Venezuela and these were sorted into two clades. Significant differentiation was detected among collections and these were genetically isolated by distance.

Key words: Aedes aegypti - genetic structure - dengue - single strand conformation polymorphism analysis - ND4 haplotypes

Dengue is the most important viral disease transmitted to human by mosquitoes in Venezuela, causing many cases of dengue fever (DF) and dengue hemorrhagic fever (DHF) annually. More than 42,199 cases (DF/DFH: 15/1) were reported through calendar year 2005 (MSDS 2006). The incidence of dengue has increased since the outbreak in 1989, because multiple serotypes are circulating in endemic areas.

Aedes aegypti is the principal vector for dengue viruses. This vector is able to maintain the four serotypes of dengue viruses (DEN 1, 2, 3, and 4) in an urban transmission cycle. Ae. aegypti populations may differ in biting behaviour, vectorial capacity, and other characteristics of epidemiological importance which may be detected through molecular markers (Tabachnick 1991). In addition, these markers could be used to determine the relatedness of geographic populations and associate this information with vector movements. This will help to analyze the risk of disease transmission (Ballinger-Crabtree et al. 1992).

Single strand conformation polymorphism (SSCP) analysis offers a simple, sensitive, and cheap method of detecting DNA polymorphisms, therefore, SSCP has become one of the most used means for determining genetic variation (Orita et al. 1989). SSCP is based on the principle that changes in the nucleotide sequences of a singlestrand DNA molecule alter its three-dimensional confor-

Financial support: Fondo Nacional de Ciencia, Tecnología e Innovación, Consejo de Desarrollo Científico y HumanísticoUC, UNDP/World Bank/WHO Special Programme for Research and Training in Tropical Diseases

${ }^{+}$Corresponding author: flormhq@cantv.net

Received 22 February 2006

Accepted 28 June 2006 mation. Point mutations could thereby change strands migration through polyacrylamide gels. SSCP detected $99 \%$ of base changes in 100 to $300 \mathrm{bp}$ DNA fragments and $89 \%$ of point mutations in $300-450$ bp molecules (Black \& DuTeau 1997, Hayashi 1991, Sunnucks et al. 2000)

An extensive population genetic study among $A e$. aegypti collections from Mexico using SSCP to analyze a 347-bp fragment amplified from the NADH dehydrogenase subunit 4 mitochondrial DNA (ND4) showed that gene flow varies by region, that collections were genetically isolated by distance in the Pacific and that the Yucatan but not among collections in the northeast (Gorrochotegui-Escalante et al. 2002). A similar study across a broad geographic area of Thailand showed a much lower genetic diversity in ND4 than the one found in Mexico. Genetic drift and vector control efforts were implicated as the principal factors in genetic differentiation (Bosio et al. 2005). Other study using the ND4 gene of Ae. aegypti only from three cities in Peru revealed low levels of genetic variability in these mosquito populations. Restricted gene flow was claimed to be responsible for population differentiation (da-Costa-da-Silva et al. 2005). The aim of this study was to investigate for the first time the population genetic structure of Ae. aegypti in different geographic regions of Venezuela using ND4 mitochondrial DNA markers.

\section{MATERIALS AND METHODS}

Mosquito collection and DNA extraction - Mosquitoes were collected as larvae between January and December 2003 and returned to the insectary in Maracay where they were reared to adults and then stored at $-70^{\circ} \mathrm{C}$ awaiting DNA extraction. Collections were obtained from eight geographic regions of Venezuela (Table I). The geographic coordinates of each locality was entered into a MapInfo Professional version 7.5 (MapInfo industry, New York). The number of mosquitoes analyzed in each collec- 
tion are listed in Table I. The DNA was extracted from individual specimens using a phenol/chloroform method, resuspended in $60 \mu \mathrm{l}$ of sterilized water and stored at $80^{\circ} \mathrm{C}$ (Rivero et al. 2004).

Mitochondrial gene amplification - A 359-bp region of the ND4 gene was amplified using the oligonucleotides and reaction conditions of Gorrochotegui et al. (2000). The PCR amplifications were carried out in $50 \mu 1$ reaction volumes using $1 \mu$ l of template DNA in a PTC-100 thermal cycler (MJ Research, Inc., Watertown, MA). Negative controls (all reagents except template) were run to detect possible contamination. Thermal cycling conditions followed (Gorrochotegui et al. 2000) except that Taq DNA polymerase was added in the mixture. The amplified products were visualized by electrophoresis in $2 \%$ agarose gels stained with ethidium bromide.

SSCP analysis - The PCR product $(10 \mu \mathrm{l})$ was mixed with $8 \mu$ of loading buffer $(10 \mathrm{mM} \mathrm{NaOH}, 95 \%$ formamide, $0.05 \%$ bromophenol blue, and $0.05 \%$ xylene cyanol), centrifuged and heated to $95^{\circ} \mathrm{C}$ for $10 \mathrm{~min}$ on a thermal cycler, then transferred immediately into ice. Samples were loaded onto $27 \times 20 \mathrm{~cm}, 1 \mathrm{~mm}$ thick, $7 \%$ polyacrylamide gels. Gels were run at $4^{\circ} \mathrm{C}$ for $20 \mathrm{~h}$ at a constant 8 milliamps and silver stained to visualize DNA fragments (Black \& DuTeau 1997).

ND4 PCR products from 3-6 individuals of each haplotype were sequenced in both directions using the PCR primers. Sequencing reactions were performed with $\mathrm{ABI}$ PRISM BigDye Terminator v3.1 Cycle Sequencing Kit on an Applied Biosystem Model 310 Genetic Analyzer at the Instituto de Estudios Avanzados (Caracas, Venezuela).

Statistical analysis of mitochondrial haplotype frequencies - Analysis of molecular variance (AMOVA) (Excoffier et al. 1992) was conducted on the resulting haplotypes within and among regions using Arlequin 2000 (Schneider et al. 2000). The significance of the variance components was computed using a non-parametric permutation test (Excoffier et al. 1992). The DNA sequences were aligned using the Clustal W software package (Thompson et al. 1994). The nucleotide sequence and the frequency of each haplotype for each collection were analyzed using DnaSP version 3.99 (Rozas et al. 2003). The number of polymorphic sites, the average number of nucleotide differences ( $\mathrm{k}$ ) (Tajima 1983), the nucleotide diversity $\left(\pi_{1}\right)$ and the nucleotide diversity with the Jukes and Cantor correction $\left(\pi_{2}\right)$ (Nei 1987) were estimated. Effective migration rates $(\mathrm{Nm})$ were calculated from $\mathrm{F}_{\mathrm{ST}}$. Transformed $\mathrm{F}_{\mathrm{ST}} /\left(1-\mathrm{F}_{\mathrm{ST}}\right)$ were regressed on the natural logarithm of pairwise geographic distances among populations to test for isolation by distance (Slatkin 1993). The Mantel test was performed using FORTRAN program MANTEL (William C. Black IV, Department of Microbiology, Immunology and Pathology, Colorado State University, Fort Collins, CO). Genetic distance matrices were used

TABLE I

Regions, locations per region, geographic coordinates, and sample sizes

\begin{tabular}{|c|c|c|c|c|}
\hline Region & Locality & Latitude & Longitude & No. individuals \\
\hline 1: West Coast (WC) & $\begin{array}{l}\text { Mecocal } \\
\text { La Esperanza } \\
\text { Los Pedros }\end{array}$ & $\begin{array}{l}-71.411 \\
-69.7711 \\
-69.0461\end{array}$ & $\begin{array}{l}10.6465 \\
10.5944 \\
10.8036\end{array}$ & $\begin{array}{l}48 \\
49 \\
48\end{array}$ \\
\hline 2: Maracaibo Lake (ML) & $\begin{array}{l}\text { Nueva Bolivia } \\
\text { Palmarito }\end{array}$ & $\begin{array}{l}-71.0873 \\
-71.2173\end{array}$ & $\begin{array}{l}9.14206 \\
9.18048\end{array}$ & $\begin{array}{l}52 \\
47\end{array}$ \\
\hline 3: West Region (WR) & $\begin{array}{l}\text { Santa María } \\
\text { Las Américas }\end{array}$ & $\begin{array}{l}-70.6239 \\
-70.9909\end{array}$ & $\begin{array}{l}9.28081 \\
8.54235\end{array}$ & $\begin{array}{l}49 \\
50\end{array}$ \\
\hline 4: Inland Region (IL) & $\begin{array}{l}\text { San Carlos } \\
\text { Calabozo } \\
\text { San Juan }\end{array}$ & $\begin{array}{c}-68.5728 \\
-67.4372 \\
-67.343\end{array}$ & $\begin{array}{c}9.68337 \\
8.9293 \\
9.92745\end{array}$ & $\begin{array}{l}45 \\
48 \\
49\end{array}$ \\
\hline 5: Central Region (CR) & $\begin{array}{l}\text { Maracay } \\
\text { El Limón } \\
\text { La Victoria } \\
\text { Cagua } \\
\text { Villa de Cura }\end{array}$ & $\begin{array}{l}-67.5914 \\
-67.6334 \\
-67.3331 \\
-67.4565 \\
-67.4807\end{array}$ & $\begin{array}{l}10.2553 \\
10.3106 \\
10.2312 \\
10.1888 \\
10.0369\end{array}$ & $\begin{array}{l}48 \\
43 \\
50 \\
47 \\
49\end{array}$ \\
\hline 6: North Region (NR) & $\begin{array}{l}\text { Puerto Cabello } \\
\text { Catia La Mar } \\
\text { Naiguatá }\end{array}$ & $\begin{array}{l}-68.0176 \\
-67.0342 \\
-66.7364\end{array}$ & $\begin{array}{l}10.4731 \\
10.6057 \\
10.6251\end{array}$ & $\begin{array}{l}41 \\
48 \\
46\end{array}$ \\
\hline 7: East Region (ER) & $\begin{array}{l}\text { Puerto Píritu } \\
\text { Barcelona } \\
\text { Sucre }\end{array}$ & $\begin{array}{l}-65.0411 \\
-64.6617 \\
-64.155\end{array}$ & $\begin{array}{l}10.0654 \\
10.1554 \\
10.4772\end{array}$ & $\begin{array}{l}50 \\
45 \\
49\end{array}$ \\
\hline 8: South Region (SR) & $\begin{array}{l}\text { Tumeremo } \\
\text { El Dorado } \\
\text { El Callao }\end{array}$ & $\begin{array}{l}-61.5049 \\
-61.6357 \\
-61.8088 \\
\end{array}$ & $\begin{array}{l}7.27414 \\
6.72379 \\
7.35699\end{array}$ & $\begin{array}{l}49 \\
47 \\
47 \\
\end{array}$ \\
\hline Total & 24 & & & 1144 \\
\hline
\end{tabular}


to construct a cladogram among all collections by means of unweighted pair-group method with arithmetic averaging analysis in the NEIGHBOR procedure of PHYLIP3.5C (Felsentein 1993).

Phylogenetic relationships among haplotypes MEGA (version 3.0) was used to perform phylogenetic analyses using maximum parsimony (Kumar et al. 2004). A bootstrap analysis with 1000 replications was done to assess the consistency with which the dataset supported the resolved phylogenies. ND4 homologous regions of Anopheles gambiae and Ae. albopictus were used as outgroups.

\section{RESULTS}

Haplotypes frequencies - A total of 24 samples, representing 1144 wild specimens of Ae. aegypti were collected in eight geographic areas defined as the West Coast (WC), the Maracaibo Lake (ML), the West Region (WR), the Inland (IL), the Central Region (CR), the North Region (NR), the East Region (ER), and the South Region (SR) (Table I).
Seven haplotypes were detected by SSCP analysis and sequencing. The haplotype sequences were aligned with other ND4 sequences from Mexico and Brazil registered in the GenBank (Mexico: GenBank \# AF334841334865; Brazil: GenBank \# AY 906835-AY 906853). All Venezuelan sequences were unique. The sequences of Bosio et al. (2005) and da Costa-da-Silva et al. (2005) are not in the GenBank. To date there are 25 haplotypes reported from Mexico (Gorrochotegui-Escalante et al. 2002), 6 from Thailand (one of the haplotypes is found in Mexico), 19 from Brazil, 3 from Peru, and 7 from Venezuela which makes a total of 60 haplotypes. To identify the Venezuelan haplotypes following the numbering listed in the literature, it will be necessary to wait until the Brazilian publication and the Thailand and Peruvian sequences are available. Therefore, we denoted them A-G. The frequencies of these haplotypes, both by region and in the whole country are shown in Fig. 1.

Only haplotypes A, C, and E were shared among all collections. Haplotype A was the most frequent (0.96$0.18)$. Haplotype $C$ was only absent from the $\mathrm{WR}$ and its

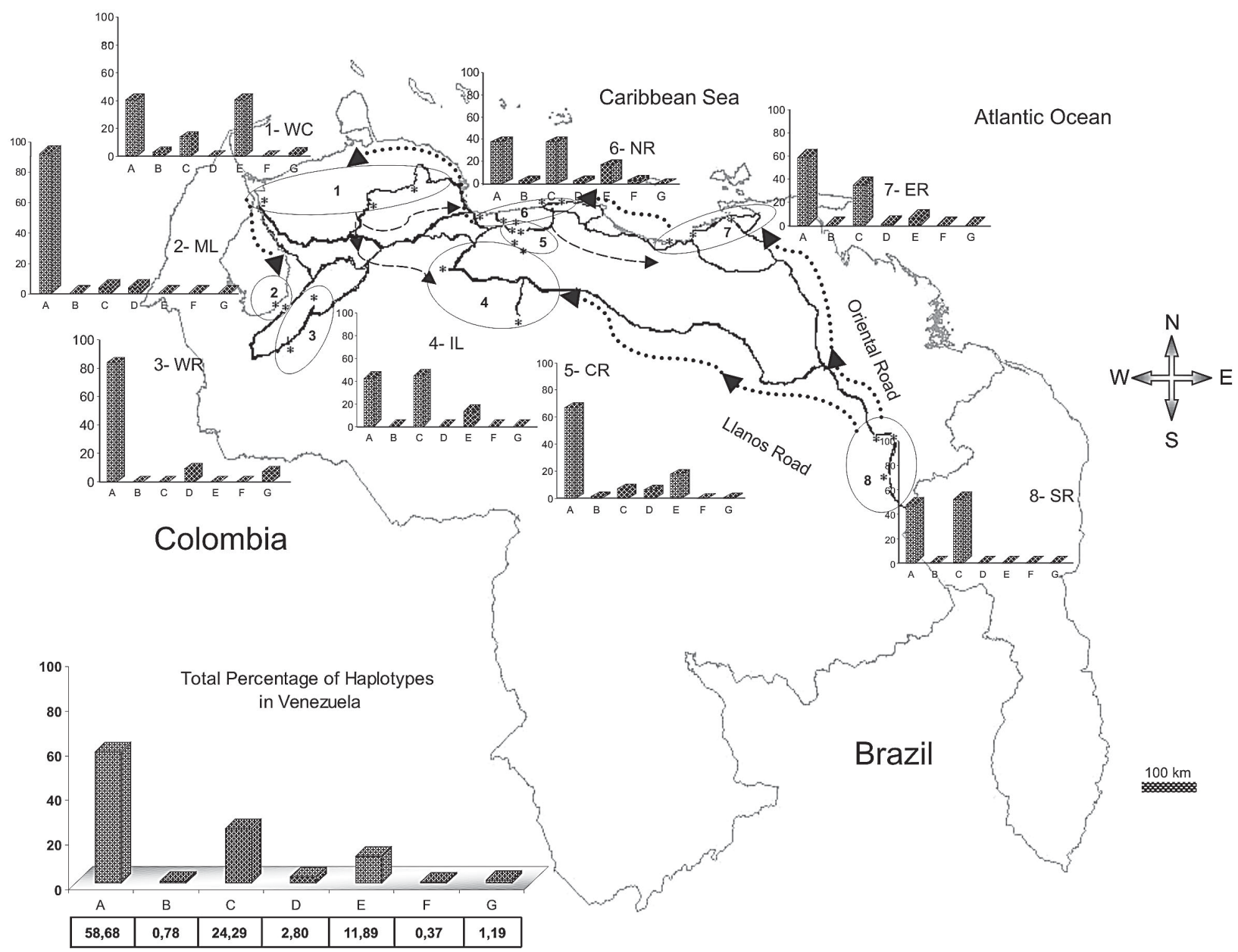

Fig. 1: map of Venezuela showing the eight geographic regions of Aedes aegypti populations. The bars indicate \% of haplotype frequencies in each region and in the lower graph the total $\%$ of haplotype frequencies in the whole country. Arrows indicate the direction of the spatial gradients of distribution of haplotypes $\mathrm{C}$ and $\mathrm{E}$. 
frequency varied from 0.64 to 0.02 . Haplotype $E$ was found in WC, NR, ER, CR, and IL. This haplotype is also distributed along a gradient of decreasing frequency $(0.81-0.06)$ but in the opposite direction of haplotype $\mathrm{C}$. The rest of the haplotypes occurred at low frequencies: Haplotype $\mathrm{D}$ was present in five regions. Haplotype $\mathrm{B}$ was present in NR, WC, and CR. Haplotype F was found only in the population of Catia La Mar in the NR whereas haplotype $\mathrm{G}$ was found in WC, WR, and NR.

Genetic heterogeneity - Geographical analysis of variation in ND4 haplotype frequencies was conducted by AMOVA (Table II). Most of the variation (77.6\%) arose among mosquitoes in collections while $11.6 \%$ arose among collections within regions and $10.8 \%$ occurred among regions. The average $\mathrm{F}_{\mathrm{ST}}$ was 0.224 suggesting substantial genetic structure among collections. In addition, the effect of the distance on levels of gene flow was estimated by regressing linearized $\mathrm{F}_{\mathrm{ST}}$ values on geographic distance (Fig. 2). This analysis indicated a significant correlation between genetic and geographic distances among all collections but no correlation was detected among collections from any particular region (data not shown).

A distance matrix containing all the pairwise linearized $\mathrm{F}_{\mathrm{ST}}$ among collections was collapsed using the UPGMA option in NEIGHBOR and the rectangular cladogram option on PHYLIP (Fig. 3). Two main clusters were detected. Cluster I contains the majority (5/7) of the collections from western Venezuela (ML, WR, WC) and from CR (4/5), while cluster II contained all of the collections from the SR, IL, and NR. The ER collections were distributed in both clusters.

We examined the frequencies of the haplotypes in both clusters. Collections in cluster I had the highest frequency of haplotype A $(\cong 0.78)$ while the majority of the collections from Cluster II had haplotype $\mathrm{C}$ in hight frequency $(\cong 0.43)$. The Los Pedros collection failed to group in either Cluster I or II. This collection contained only haplotypes $\mathrm{A}$ and $\mathrm{E}$ and the frequency of the latter was 0.81

Haplotype diversity - The number of polymorphic sites and the diversity indices for each collection and for all mosquitoes are listed in Table III. The majority of collections had similar numbers of polymorphic sites and diversity indices. However, collections from Western Venezuela with the exception of WC, had lower values of $\mathrm{k}, \pi_{1}$
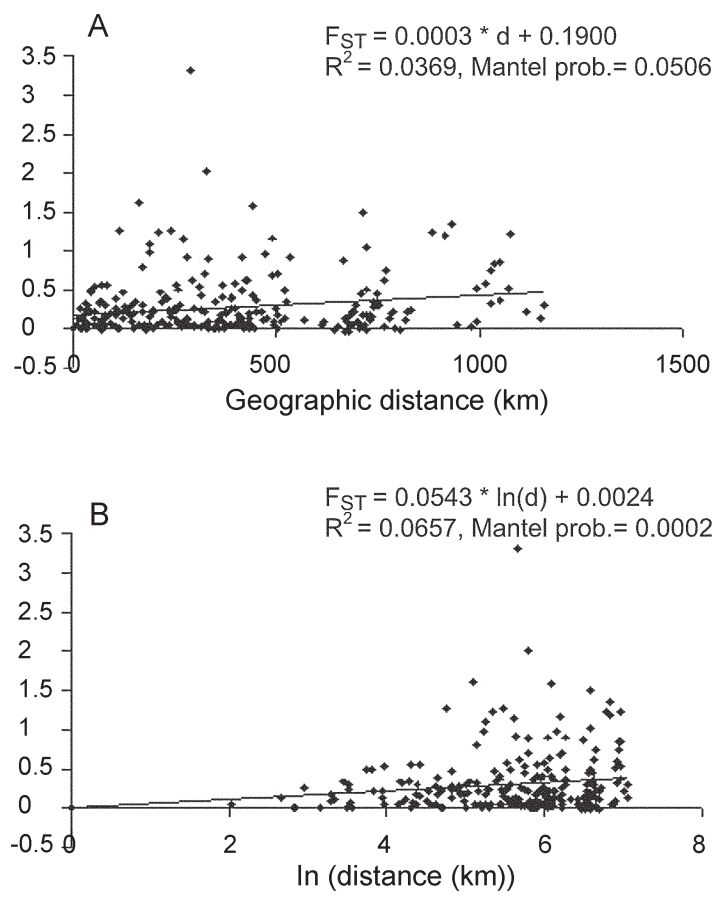

Fig. 2: Mantel regression results show isolation by distance for Aedes aegypti in Venezuela. A: Pairwise $\mathrm{F}_{\mathrm{ST}} /\left(1-\mathrm{F}_{\mathrm{ST}}\right)$ regressed on pairwise geographic distance among all collections; $\mathrm{B}$ : Pairwise $\mathrm{F}_{\mathrm{ST}}{ }^{\prime}$ $\left(1-\mathrm{F}_{\mathrm{ST}}\right)$ regressed on pairwise natural logarithm transformed geographic distances.

and $\pi_{2}$, especially the Nueva Bolivia collection in which values were at least one order of magnitude lower than all others.

Phylogenetic analysis - Phylogenetic analysis provided a well-supported phylogeny with one maternal lineage and the presence of another minor lineage. Haplotypes A-F were monophyletic while the haplotype G occurred in a separate clade (Fig. 4).

\section{DISCUSSION}

In this study we found that Ae. aegypti collections from different geographic regions of Venezuela were genetically differentiated even at the minimum distance studied $(\leq 15 \mathrm{~km}$; ML region). This suggests a very restricted level of interchange of genes among collections. This genetic differentiation arose in part to geographic dis-

TABLE II

Analysis of molecular variance in the frequency of ND4 haplotypes among Aedes aegypti collections in Venezuela

\begin{tabular}{|c|c|c|c|c|c|}
\hline Source of variation & Degrees of freedom & Variance components & Variation $(\%)$ & Fixation index & $\mathrm{P}$ \\
\hline Among regions & 7 & 0.32712 & 10.81 & $\mathrm{~F}_{\mathrm{CT}}=0.108$ & 0.01 \\
\hline Among collections within regions & 16 & 0.35044 & 11.58 & 0.130 & $<10^{-5}$ \\
\hline Within collections & 1120 & 2.34743 & 77.60 & $\mathrm{~F}_{\mathrm{ST}}^{\mathrm{SC}}=0.224$ & $<10^{-5}$ \\
\hline Total & 1143 & 3.02499 & & & \\
\hline
\end{tabular}

Fixation indices: $\mathrm{F}_{\mathrm{ST}}$, correlation among haplotypes within collections relative to the correlation of random pairs drawn from the whole sample; $\mathrm{F}_{\mathrm{SC}}$, correlation among haplotypes within collections relative to the correlation of random pairs drawn from the region; $\mathrm{F}_{\mathrm{CT}}$, correlation among haplotypes within regions relative to the correlation of random pairs drawn from the whole sample. 
TABLE III

Variability estimates in the mitochondrial genome among Aedes aegypti collections in Venezuela

\begin{tabular}{|c|c|c|c|c|c|}
\hline & No. & Polymorphic sites & $\mathrm{k}$ & $\pi_{1}$ & $\pi_{2}$ \\
\hline West Coast & 145 & 16 & 6.685 & 0.02065 & 0.02115 \\
\hline Mecocal & 48 & 14 & 6.202 & 0.01915 & 0.01962 \\
\hline La Esperanza & 49 & 16 & 6.681 & 0.02065 & 0.02114 \\
\hline Los Pedros & 48 & 12 & 3.832 & 0.01181 & 0.01212 \\
\hline Maracaibo Lake & 99 & 13 & 1.258 & 0.00390 & 0.00398 \\
\hline Nueva Bolivia & 52 & 11 & 0.849 & 0.00262 & 0.00268 \\
\hline Palmarito & 47 & 13 & 1.696 & 0.00527 & 0.00536 \\
\hline West Region & 99 & 13 & 3.172 & 0.00980 & 0.01004 \\
\hline Santa María & 49 & 12 & 3.769 & 0.01162 & 0.01193 \\
\hline Las Américas & 50 & 10 & 2.510 & 0.00777 & 0.00794 \\
\hline Inland Region & 142 & 14 & 6.259 & 0.01936 & 0.01980 \\
\hline San Carlos & 45 & 14 & 6.384 & 0.01975 & 0.02020 \\
\hline Calabozo & 48 & 11 & 5.752 & 0.01777 & 0.01820 \\
\hline San Juan & 49 & 11 & 5.689 & 0.01758 & 0.01800 \\
\hline Central Region & 237 & 18 & 5.142 & 0.01589 & 0.01627 \\
\hline Maracay & 48 & 12 & 4.967 & 0.01532 & 0.01572 \\
\hline El Limón & 43 & 14 & 2.569 & 0.00792 & 0.00813 \\
\hline La Victoria & 50 & 16 & 6.889 & 0.02130 & 0.02180 \\
\hline Cagua & 47 & 16 & 4.470 & 0.01383 & 0.01414 \\
\hline Villa de Cura & 49 & 15 & 3.835 & 0.01191 & 0.01213 \\
\hline North Region & 135 & 18 & 6.535 & 0.02022 & 0.02068 \\
\hline Puerto Cabello & 41 & 11 & 5.357 & 0.01655 & 0.01695 \\
\hline Catia la mar & 48 & 18 & 6.104 & 0.01890 & 0.01932 \\
\hline Naiguatá & 46 & 16 & 6.631 & 0.02053 & 0.02098 \\
\hline East Region & 144 & 16 & 5.820 & 0.01799 & 0.01841 \\
\hline Puerto Píritu & 50 & 11 & 3.944 & 0.01219 & 0.01248 \\
\hline Barcelona & 45 & 16 & 5.245 & 0.01623 & 0.01660 \\
\hline Sucre & 49 & 14 & 5.492 & 0.01696 & 0.01737 \\
\hline South Region & 143 & 11 & 5.657 & 0.01748 & 0.01790 \\
\hline Tumeremo & 49 & 11 & 5.631 & 0.01740 & 0.01782 \\
\hline El Dorado & 47 & 11 & 5.438 & 0.01680 & 0.01721 \\
\hline El Callao & 47 & 11 & 5.730 & 0.01771 & 0.01813 \\
\hline All samples & 1144 & 18 & 6.073 & 0.01877 & 0.01922 \\
\hline
\end{tabular}

k: the mean number of nucleotide differences; $\pi_{1}$ : nucleotide diversity; $\pi_{2}$ : nucleotide diversity with Jukes and Cantor correction.

tance. Geographic barriers may limit gene flow. However throughout most of these regions there is intense terrestrial and air traffic. There is a significant correlation between gene flow in Ae. aegypti and human transportation (Craven et al. 1988, Garcia-Franco et al. 2002, Gorrochotegui-Escalante et al. 2002, Huber et al. 2004, daCosta-da-Silva et al. 2005, Merril et al. 2005). In addition, there were large $\mathrm{F}_{\mathrm{ST}}(0.221)$ values among collections made across uniform habitats such as the sea coast separated by $<50 \mathrm{~km}$ (Fig. 2). Other possibility may be a strong reduction in the effective population size in collections caused by insecticide applications. The presence of only three major haplotypes, unique haplotypes or haplotypes with very small frequencies in some regions could arise due to major population bottlenecks caused by insecticide treatment. Similarly, Ayres et al. (2004) have reported that Brazilian populations of Ae. aegypti showed high levels of genetic differentiation in areas most frequently treated with chemical insecticides. Other investigators suggested that insecticide pressure is probably the major cause of genetic diversity in Ae. aegypti from highly populated urban areas (Paupy et al. 2000, Ocampo \& Wesson 2004).

Ae. aegypti in Venezuela have been exposed to chemical insecticides since 1945 when the use of DDT started (Berti et al. 1960). Then, 30 years ago, the intense use of three organophosphates began with malathion and fenithrothion used for adult control and temephos as a larvicide. Insecticide treatments have probably exerted intense selection on the populations and caused severe bottlenecks during vector control efforts. The use of insecticides has also facilitated the appearance of insecticide resistance in Ae. aegypti (Bisset et al. 2001, Rodríguez et al. 2001)

The effective migration rate among even nearby collections was low, suggesting reduced gene flow. The 
distribution of haplotypes $\mathrm{C}$ and $\mathrm{E}$ followed a gradual change in frequency along two spatial gradients. Haplotype $\mathrm{C}$ from the south to the west region separated by a distance of $1160 \mathrm{~km}$ and the $\mathrm{E}$ from the west to the east separated by $794 \mathrm{~km}$. The spread of these haplotypes followed the main roads between localities that are used in extended human commerce (Fig. 1).

Cluster analysis of collections from the eight regions shows two main clusters principally associated with the frequency of haplotypes A and C. Haplotype C was most frequent in the SR collections and probably disseminated to nearby regions. Haplotype A was common to all collections with a frequency $\geq 0.18$. However, it was most frequent in WR $(84 \%)$ and ML (92\%) which suggests that haplotype A originated or was introduced into western Venezuela. The Los Pedros collection was separated from the rest of the collections because it contained the highest frequency for the haplotype $\mathrm{E}(0.81)$ and was similar to the Catia La Mar collection in having the lowest frequency of haplotype A (0.18). The Los Pedros collection apparently underwent a bottleneck. Los Pedros is a town near a main road (Carretera Zulia-Falcón), $\sim 15 \mathrm{~km}$ away from the WC. However, it may be an "ecological island" since it is surrounded by kilometers of sand dunes and few plants are able to grow in the lower sections of the dunes.

Phylogenetic analysis of haplotype sequences demonstrated two clades. Probably, the oldest clade of $A e$. aegypti in Venezuela is represented by the clade that groups the majority of the haplotypes. Besides it has an even geographic distribution showing a frequency of $99 \%$ in the whole country. The other lineage occurs at very low frequency $(1 \%)$ and it is mainly confined to the western region. In the monophyletic group, the common haplotype A $(58.6 \%)$ is split from the two other major haplotypes, C (24.2\%) and E (11.8\%), in different groups, although they clustered individually only $65 \%$ of the time. Based on this low bootstrap value, the two groups cannot be considered completely distinct. However, it is tempting to speculate that haplotype A contributed to the Ae. aegypti gene pool more anciently than the other haplotypes since it is widespread in Venezuela and it has, apparently, less evolutionary changes than the other haplotypes.

Analysis of additional populations from North, Central, and South America countries will reveal historical and phylogeographic patterns for Ae. aegypti in these

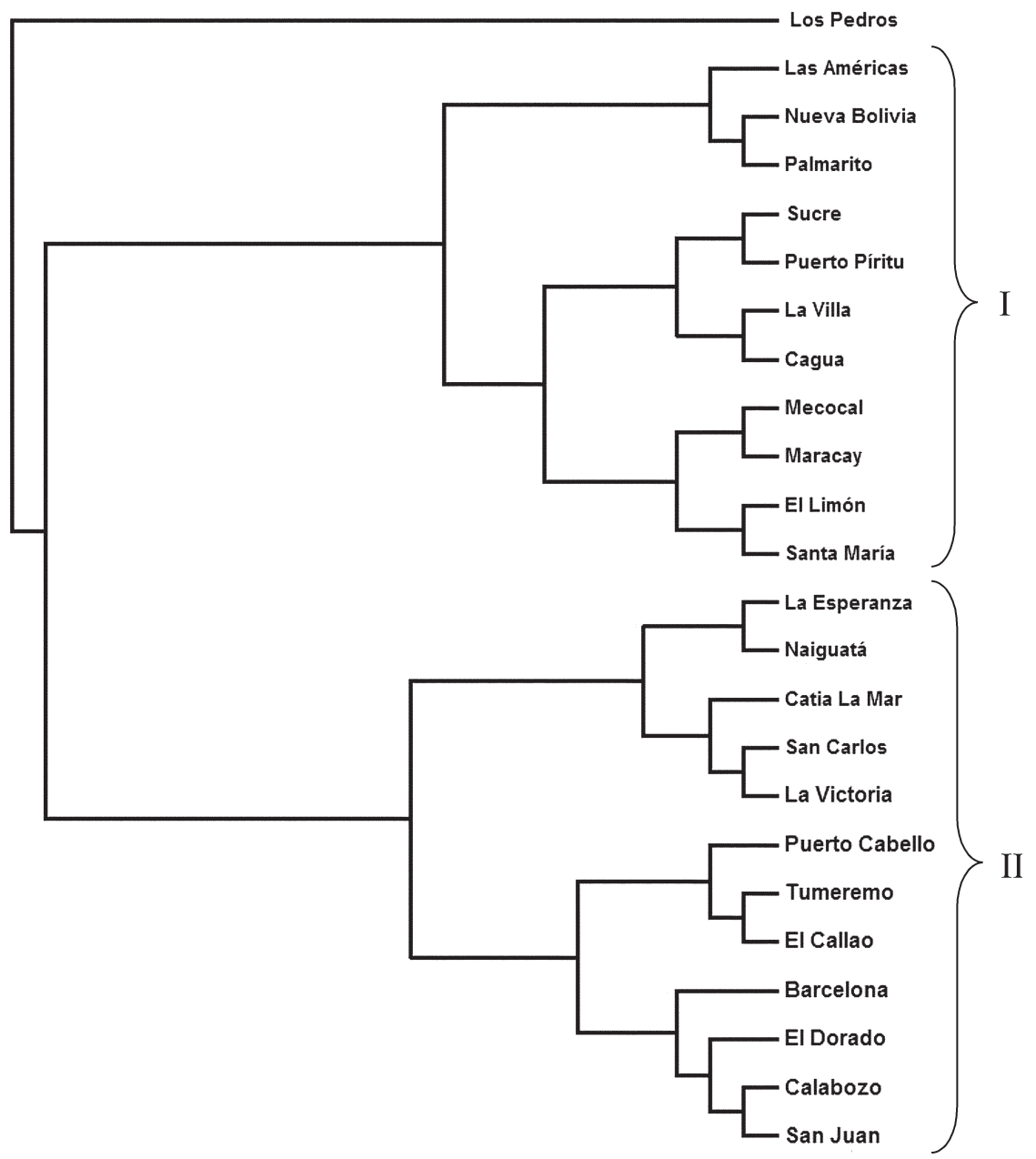

Fig. 3: Unweighted pair-group method with arithmetic averaging cluster analysis of pairwise $\mathrm{F}_{\mathrm{ST}} /\left(1-\mathrm{F}_{\mathrm{ST}}\right)$ genetic distances between Aedes aegypti populations. 


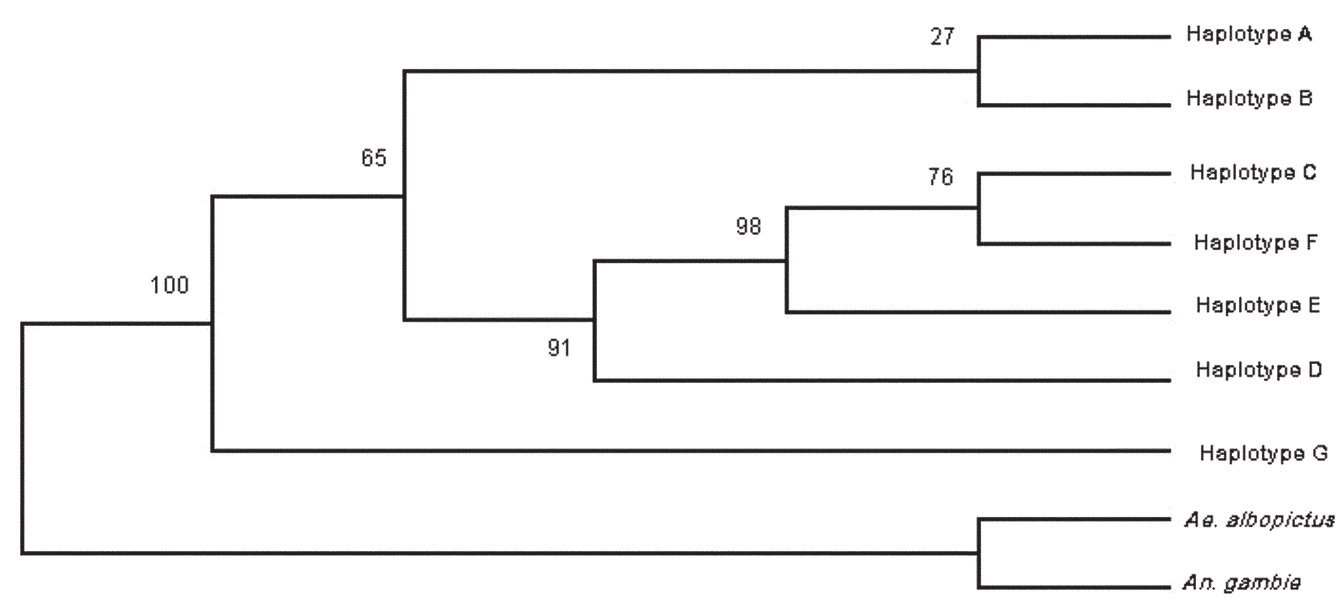

Fig. 4: Maximum parsimony tree showing phylogenetic relationships among individual haplotypes. Bootstrap support using maximum parsimony analysis appears above each branch.

countries. Such knowledge will allow testing from where the haplotypes were introduced into Venezuela. Results can have importance in revealing differences in selection by insecticide resistance genes in Aedes during its dispersal and evolution.

We compared our data of ND4 in Ae. aegypti with similar studies from Mexico Thailand and Peru. Within Mexico, Thailand, and Peru were identified 25, 7, and 3 haplotypes respectively. Our results are more consistent with the ones from Thailand since we found also seven haplotypes. We detected seven haplotypes but only A, $\mathrm{C}$, and $\mathrm{E}$ had appreciable frequencies. The frequencies of these haplotypes varied geographically following two gradientes.

The comparison of our haplotype sequences with similar ones registered in the GenBank (Mexico and Brazil) demonstrated that all the haplotypes found are unique to Venezuela. We also compared the genetic variability of our samples with the ones from Mexico, Thailand and Peru. Mexico has a greater genetic diversity (2-3 times) than Thailand and Peru that could be explained because Mexico has more haplotypes than Thailand ( $>3$ times) and Peru ( $>8$ times). Our results exhibit a mixed behaviour. We have only seven haplotypes, a low number like Thailand and Peru, but the genetic diversity pattern was similar to Mexico.

In addition, the data presented here could have important implications for dengue transmission since the genetic variability in Ae. aegypti from Venezuela may cause differences in their susceptibility to dengue virus. Information obtained from the Venezuelan Ministry of Health (2006) gave support for this idea. In 2005, dengue has become endemic in the majority of the Venezuelan territory. Nevertheless, there are localized regions over the northeastern parts of the country which are not considered dengue risk areas.

A correlation between population differentiation and heterogenous patterns of vector competence in $A e$. aegypti has been suggested for other authors (Tran et al.
1999, Vazeille-Falcoz et al. 1999, 2001, Paupy et al. 2000, 2003, Black WC 4th et al. 2002, García-Franco et al. 2002, Lourenço-de-Oliveira et al. 2004, Ocampo \& Wesson 2004). A population genetic analysis and an evaluation to susceptibility to dengue 2 virus were conducted among Ae. aegypti samples from different states of Brazil (Laurenço-de-Oliveira et al. 2004). It was demonstrated that Brazilian Ae. aegypti were genetically differentiated within most of the regions, and that their infection rates towards DENV2 were heterogenous. Other study has found a correlation between genetic distances of $A e$. aegypti populations and their infections rates (GarcíaFranco et al. 2002).

This study suggests that the Venezuelan vector control programme may induce recurrent emergence of insecticide-resistant populations. Moreover, the rapid fixation of haplotypes conferring insecticide resistance could take place; the resistant populations may be spread at a larger scale as the migration of resistant mosquitoes could be facilitated over the one of susceptible insects. Ae. aegypti resistant to insecticides represent a great problem in dengue control. The next step will be to look for insecticide resistance in the studied populations to confirm the involvement of selection effects in the actual genetic structure of Venezuelan Ae. aegypti population.

\section{ACKNOWLEDGEMENTS}

To Alfredo Sánchez and Marcel Sánchez for helping us with the MapInfo Program, Elizabeth Ferrer for advice on the Clustal Program, Esteban Arroyo and Luis Pérez for help with the Arlequin Program, Flor Angel Tovar for technical assistance on sequencing the samples, Omar Cornejo for advice us on statistical analysis on preliminary work, Victor Sánchez and Hernán Guzmán for the collection of mosquitoes and William C Black IV for critical reading of the manuscript.

\section{REFERENCES}

Ayres CEJ, Melo-Santos MAV, Prota JRM, Solé-Cava AM, Regis L, Furtado AF 2004. Genetic structure of natural populations of Aedes aegypti at the micro- and macrogeo- 
graphic levels in Brazil. J Am Mosq Control Assoc 20: 350356

Ballinger-Crabtree ME, Black IV WC, Miller BR 1992. Use of genetic polymorphisms detected by the random-amplified polymorphic DNA polymerase chain reaction (RAPD-PCR) for differentiation and identification of Aedes aegypti subspecies and populations. Am J Trop Med Hyg 47: 893-901.

Berti AL, Gabaldón A, Guerrero 1, Gómez Nuñez JC 1960. 25 years of antimalarial struggle in Venezuela (1936-1960). Riv Ital Ig 25: 33-48.

Bisset JA, Rodriguez MM, Molina D, Diaz C, Soca LA 2001. High esterases as mechanism of resistance to organophosphate insecticides in Aedes aegypti strains. Rev Cubana Med Trop 53: 37-43.

Black WC IV, Bennett KE, Gorrochotegui-Escalante N, BarillasMury CV, Fernández-Salas I, de Lourdes Muñoz M, FarfanAle JA, Olson KE, Beaty BJ 2002. Flavivirus susceptibility in Aedes aegypti. Arch Med Res 33: 379-88.

Black IV WC, Du Teau NM 1997. RAPD-PCR and SSCP analysis for insect population genetic studies. In J Crampton, CB Beard, C Louis, The Molecular Biology of Insect Disease Vectors: A Methods Manual, Chapman and Hall, New York, p. 361-373.

Bosio ChF, Harrington LC, Jones JW, Sithiprasasna R, Norris DE, Scott TW 2005. Genetic structure of Aedes aegypti populations in Thailand using mitochondrial DNA. Am J Trop Med Hyg 72: 434-442.

Craven RB, Eliason DA, Francy DB, Reiter P, Campos EG, Jakob WL, Smith GC, Bozzi CJ, Moore CG, Maupin GO, Monath TP 1988. Importation of Aedes albopictus and other exotic mosquito species into the United States in used tires from Asia. J Am Mosq Control Assoc 4: 138-142.

da-Costa-da-Silva AL, Capurro ML, Bracco JE 2005. Genetic lineages in the yellow fever mosquito Aedes (Stegomyia) aegypti (Diptera: Culicidae) from Peru. Mem Inst Oswaldo Cruz 100: 539-544.

Excoffier L, Smouse PE, Quattro JM 1992. Analysis of molecular variance inferred for metric distances among DNA haplotypes: application to human mitochondrial DNA restriction data. Genetics 131: 479-491.

Felsenstein J 1993. PHYLIP, Phylogeny Inference Package. Version 3.5C. Seattle, WA, University of Washington.

García-Franco F, Muñoz Mde L, Lozano-Fuentes S, FernándezSalas I, García-Rejon J, Beaty BJ, Black WC 4th 2002. Large genetic distances among Aedes aegypti populations along the South Pacific coast of Mexico. Am J Trop Med Hyg 66: 594-598.

Gorrochotegui-Escalante N, Gómez-Machorro C, LozanoFuentes S, Fernández-Salas I, Muñoz M, Farfan-Ale, García-Rejon J, Beaty B, Black IV W 2002. Breeding structure of Aedes aegypti populations in Mexico varies by region. Am J Trop Med Hyg 66: 213-222.

Gorrochotegui-Escalante N, Muñoz M, Fernández-Salas I, Beaty B, Black IV W 2000. Genetic isolation by distance among Aedes aegypti populations along the notheastern coast of Mexico. Am J Trop Med Hyg 66: 213-222.

Hayashi K 1991. PCR-SSCP: a simple and sensitive method for detection of mutations in the genomic DNA. PCR Methods Appl 1: 34-38.
Huber K, Loan LL, Chantha N, Failloux AB 2004. Human transportation influences Aedes aegypti gene flow in Southeast Asia. Acta Trop 90: 23-29.

Kumar S, Tamura K, Nei M 2004. MEGA 3: Integrated software for Molecular Evolutionary Genetics Analysis and Sequence Alignment. Briefings in Bioinformatics 5: 150163.

Lourenço-de-Oliveira R, Vazeille M, de Filippis AMB, Failloux AB 2004 Aedes aegypti in Brazil: genetically differentiated populations with high susceptibility to dengue and yellow fever viruses. Tran R Soc Trop Med Hyg 98: 43-54.

Merril S, Ramberg F, Hagedorn H 2005. Phylogeography and population structure of Aedes aegypti in Arizona. Am J Trop Med Hyg 72: 304-310

MSDS 2006. Ministerio de Salud y Desarrollo Social. Dirección de Salud Ambiental. Boletín Epidemiológico, Semana No 52 (from $01 / 01 / 2005$ to $31 / 12 / 2005$ ). Available at: www. msds.gov.ve.

Nei M 1987. Molecular Evolutionary Genetics, Columbia University Press, New York.

Ocampo CB, Wesson DM 2004. Population dynamics of Aedes aegypti from a dengue hyperendemic urban setting in Colombia. Am J Trop Med Hyg 71: 506-513.

Orita M, Iwahana H, Kanazawa H, Hayashi K, Sekiya T 1989. Detection of polymorphisms of human DNA by gel electrophoresis as SSCPs. Proc Natl Acad Sci USA 86: 27662770.

Paupy C, Chantha N, Vazeille M, Reynes JM, Rodhain F, Failloux AB 2003. Variation over space and time of Aedes aegypti in Phnom Penh (Cambodia): genetic structure and oral susceptibility to a dengue virus. Genet Res $82: 171-82$.

Paupy C, Vazeille-Falcoz M, Mousson L, Rodhain F, Failloux AB 2000. Aedes aegypti in Tahiti and Moorea (French Polynesia): isoenzyme differentiation in the mosquito population according to human population density. Am J Trop Med Hyg 62: 217-224.

Rivero J, Urdaneta L, Zoghbi N, Pernalete M, Rubio-Palis Y, Herrera F 2004. Optimization of extraction procedure for mosquito DNA suitable for PCR-based techniques. Intern J Trop Insect Sci 24: 266-269.

Rodríguez MM, Bisset J, de Fernández DM, Lauzan L, Soca A 2001. Detection of insecticide resistance in Aedes aegypti (Diptera: Culicidae) from Cuba and Venezuela. $J$ Med Entomol 38: 623-628.

Rozas J, Sánchez-DelBarrio JC, Messeguer X, Rozas R 2003. DnaSP, DNA polymorphism analyses by the coalescent and other methods. Bioinformatics 19: 2496-2497.

Schneider S, Roessli D, Excoffier L 2000. ARLEQUIN, Version 2.000: A software for Population Genetic Data Analysis. Genetics and Biometry Laboratory, University of Geneva, Geneva.

Slatkin M 1993. Isolation by distance in equilibrium and nonequilibrium populations. Evolution 47: 264-279.

Sunnucks P, Wilson AC, Beheregaray LB, Zenger K, French J, Taylor AC 2000. SSCP is not so difficult: the application and utility of single-stranded conformation polymorphism in evolutionary biology and molecular ecology. Mol Ecol 9: $1699-1710$ 
Tabachnick WJ 1991. Evolutionary genetics and arthropodborne disease. The yellow fever mosquito. Am Entomol 37: $14-23$.

Tajima F 1983. Evolutionary relationship of DNA sequences in finite populations. Genetics 105: 437-460.

Thompson JD, Higgins DG, Gibson TJ 1994. CLUSTAL W: improving the sensitivity of progressive multiple sequence alignment through sequence weighting, position-specific gap penalties and weight matrix choice. Nucleic Acids Res 22: 4673-4680.

Tran KT, Vazeille-Falcoz M, Mousson L, Tran HH, Rodhain F, Ngugen TH, Failloux AB 1999. Aedes aegypti in Ho Chi
Minh City (Viet Nam): susceptibility to dengue 2 virus and genetic differentiation. Trans R Soc Trop Med Hyg 93: 581-586.

Vazeille-Falcoz M, Mousson L, Rodhain F, Chungue E, Failloux AB 1999. Variation in oral susceptibility to dengue type 2 virus of populations of Aedes aegypti from the islands of Tahiti and Moorea, French Polynesia. Am J Trop Med Hyg 60: 292-299.

Vazeille-Falcoz M, Mousson L, Rakatoarivony I, Villeret R, Rodhain F, Duchemin JB, Failloux AB 2001. Population genetic structure and competence as a vector for dengue type 2 virus of Aedes aegypti and Aedes albopictus from Madagascar. Am J Trop Med Hyg 65: 491-497. 
